\title{
Municipal Representatives’ Accounts of Decision-Making Practices during Geriatric Case Conferences ${ }^{1}$
}

\begin{abstract}
This article addresses questions of elucidation in talk-in-interaction. How do social actors give accounts of what they are doing? To what degree do actors sustain a taken-for-granted level of reasoning? The analysis is based upon naturally occurring data consisting of a corpus of audio recorded case conferences at various geriatric wards in Danish hospitals. The article elaborates one of the important insights of Harold Garfinkel regarding the relationship between discourse and social interaction: as a general characteristic, people tend to treat their fellow interlocutors' conversational contributions as adequate for-all-practical-purposes. Specifically, the article investigates how Danish municipal representatives account for their decisions about whether or not senior citizens are to be referred to residential homes. This practice, I demonstrate, is characterized by non-explicitness with regards to rules and regulations. Instead, municipal representatives make use of developmental discourse: a worsened condition is used to justify a referral to a residential home. On the other hand, an improved condition is used to justify that an elderly citizen is not referred to a residential home.
\end{abstract}

\section{Introduction}

The definite and sensible character of the matter that is being reported is settled by an assignment that reporter and auditor make to each other that each will have furnished whatever unstated understandings are required. Much therefore of what is actually reported is not mentioned. (Garfinkel 2003: 3)

Language is among the most important resources for conducting practical action in our everyday lives. Arguably, it is the single most important resource available. But unlike, for instance, mathematicians, logicians and computer programmers who must all strive for exhaustive precision in their formal languages, social actors voice only very little of what is communicated and grasped in everyday life explicitly. The rest remains tacit. It is neither necessary nor suitable to explicitly voice all the information which we communicate and grasp.

Descriptions of states of affairs in everyday life can never be fully exhaustive, since at any time alternative ways can be found to describe the states of affairs. This fact is an important reason why social actors assume conversational contributions to be motivated (i.e., produced for a reason), relevant (i.e., according to the ongoing activities) and for-all-practical-purposes adequate (i.e., conveyed adequately detailed in order to carry out the task at hand). In this paper, I'll show that in very important moments during a particular conversational setting, there is not an either/ or choice between explicitly voicing something or not. Rather, since what is accepted as an adequate contribution is dynamic and locally determined, it is more appropriate to think of explicit voicings as continuums. My analyses concern how municipal representatives in Denmark refer elderly citizens to residential homes after hospitalization in the geriatric wards of Danish hospitals. In particular, the analyses concentrate on how municipal representatives during geriatric case

1 I am indebted to Jeffrey Parrot and, not least, to the anonymous reviewers for illuminating comments to prior versions of this paper.

\footnotetext{
* Søren Beck Nielsen

University of Copenhagen, Faculty of Humanities

Department of Nordic Studies and Linguistics

Njalsgade 136

DK-2300 Copenhagen $S$

sbnielsen@hum.ku.dk
} 
conferences account for their decisions about whether or not senior citizens are to be referred to residential homes.

\section{Data, method and organization of the paper}

The elderly are a section of the population that is particularly exposed to illness and accidents. In Denmark, more than half of all patients who are hospitalized with immediate need of help are over 65 years old. To comply with this need, most of the larger Danish hospitals have established geriatric wards. After having been hospitalized in a geriatric ward, the patient is discharged with a case conference. Typically, these conferences are multi-person interactions in which doctors, nurses, physiotherapists, municipal representatives in charge of home-help service distribution and residential home placement for the elderly, patients and their relatives participate. During the conferences, the participants decide the further course of action for the patients. This often involves a decision about whether they will move back to their own homes and possibly receive home help (for interaction analytic studies of encounters between home help representatives and citizens in their homes in Denmark, see Heinemann $(2006,2008)$ ), or if they will move into a residential home. For the patients personally, these decisions are of the utmost importance. It is decided if the patients are to radically change the way they live their everyday lives. In some cases it is decided where the patients are to spend the rest of their lives.

Both of these two options, home-help service and a place in a residential home, are practically free in Denmark; they are paid for by the municipality. But in order to receive this help, the elderly have to be referred by a municipal representative. On the other hand, in order to put impaired patients in either a home-help program or a residential home, it is legally required that the patients themselves agree. Some patients do not desire help because they feel able to take care of themselves, and in some cases other participants attempt to talk the patients into receiving help. So, quite often, a negotiation takes place.

This study seeks from an ethnomethodological point of view to illuminate members' achievement of common understanding, in particular, how municipal representatives in situ convey their understandings of the patients' conditions when they argue for a particular residential solution. The method is supplied with conversation analysis in order to investigate the sequential organization of the turns-of-talk in which these understandings are conveyed. The study draws upon twelve audio-recorded case conferences in the geriatric wards of six different Danish hospitals. The conferences were recorded between 2002 and 2004 and their lengths vary between 20 and 40 minutes, with an average of approximately 30 minutes. Recordings were made by the author with the written consent of every participant. The recordings where transcribed by the author in accordance with the general conversation analytic standard (see e.g. Heritage/Atkinson 1984). All names have been made anonymous and references to places or institutions have been blurred.

This paper focuses on two cases in particular: an instance where a patient is granted her request to move into a residential home and an instance from another hospital where another patient is denied her request to move into a residential home. Together, these two instances illustrate that acceptances as well as rejections are accounted for in similar loose ways.

Before moving on to analyses of the two cases, I briefly discuss a) the general issue of giving accounts, $b$ ) the issue of finding the proper categories in decision-making processes and, finally, c) a particular device that municipal representatives use when they describe the patients' conditions and, thereby, provide accounts of why the patients are to be referred to residential homes or not.

\section{Accounts and accountable actions}

An initial observation of the practice of referring elderly citizens to residential homes, which is less trivial than it may sound, is the fact that municipal representatives do give accounts of their decisions. Many, if not most, social actions in everyday life rests upon tacit decisions; that is, pros, cons, motives and considerations in general are not explicitly voiced. However, social ac- 
tions and the decisions they may rest upon are frequently explained. So, in terms of reasoning, one might speak of two levels:

\begin{abstract}
On the one hand, there is the taken-for-granted level of reasoning through which a running index of action and interaction is created and sustained. On the other, there is the level of overt explanation in which social actors give accounts of what they are doing in terms of reasons, motives or causes. (Heritage, 1988: 128)
\end{abstract}

Thus, when people explain or justify their conduct, that is, give accounts of their actions, they transcend the talk-in-interaction from the taken-for-granted level of reasoning to a level of overt explanation. The notion of explaining and justifying behaviour can be traced back to philosophical (Austin 1961) and sociological (Mills 1940; Scott/Lyman 1968) roots, and it has been elaborated, among other, from a psychological perspective (Shotter 1984). Within the last couple of decades it has been studied extensively and empirically within the traditions of ethnomethodology and conversation analysis. Some of these many studies include how boys account for why they refuse to engage in an activity (Goodwin/Goodwin 1990: 94-95); how call takers may justify a refusal to engage in a talk (Maynard/Schaeffer 1997); how someone may seek to dismiss criticism with an account (Schegloff 1988); and how people often produce accounts when they pass on an invitation or refuse to accommodate a request (Davidson 1984; Drew 1984; Schegloff 1984, 2007). These documented cases support Harvey Sacks' claim that, regularly, one knows when one is doing an accountable act (1992: 19). Altogether, they support the general claim that account giving is a normatively required feature of unexpected or unlooked-for actions and, thereby, a central element in social interaction (for larger, coherent conversation analytic informed introductions to this issue, see Buttny (1993) and Antaki (1994)).

In the situation, municipal representatives account for their decisions regarding whether or not senior citizens are to be referred to residential homes. This fact does not necessarily mean that the decisions are construed as unexpected or unlooked-for actions. It might just as well indicate that account giving is a normatively required feature of important decision making in institutional interaction. Maynard/Manzo (1993) have, for instance, shown that jurors, throughout the entire process of deliberation, seek to assign the verdict its legitimate history by continuously accounting for reflections and pros and cons.

\title{
4. Proper social categories
}

For the actors, institutional decision-making processes are often a matter of locating and, in particular, agreeing upon the proper social categories. This certainly applies to the Scandinavian welfare system. The Scandinavian welfare system is characterized by a high degree of (tax-funded) public assistance. In Denmark, for instance, a series of social reforms from the late 1960s to the mid 1970s established a universal state-run healthcare system financed through general taxes. In this system, public assistance is meant to be tailored to the needs of the individuals and their specific circumstances (Christiansen/Petersen 2001). In order to provide public assistance, a vast number of social workers are employed by the state. One of their most central tasks is gate keeping, that is, to meet with the citizens, assess their needs and accommodate the necessary and entitled assistance. Legally, the Danish Social Services Law (§ 140) provides municipal representatives authority to assess the needs of elderly citizens. On the basis of interaction-analytic studies of encounters between social workers and clients at unemployment offices in Sweden, Linell/Fredin (1995) have illustrated how negotiation over outcomes (i.e., the amount of financial aid if any) unfolds as competing interpretations of relevant categories:

There is an intrinsic, and highly significant, relation between outcomes and category definitions in negotiation activities. That is, if certain decisions are taken in an encounter, this presupposes at least implicit contextual (or situated) interpretations of relevant categories. Conversely, if you can agree on definitions and applications of relevant categories, then the outcomes largely follow from these agreements. (Linell/Fredin 1995: 314) 
A very large amount of research on decision-making processes in institutional interaction has documented the great impact of such categorization practices. In bureaucracy, categorization of clients is the predominant tool professionals use in order to grasp and treat clients' cases accordingly (Prottas 1979); In court room cross-examination attorneys and witnesses negotiate categories in the witnesses' tellings, for instance, did the victim and the accused in a rape case go to a 'bar' or a 'club' before the alleged rape took place? The agreement of one or the other category ultimately affects the parties' credibility (Drew 1992); Teachers and other school staff regularly engage in the classification of students to sort out who are 'normal' and who are 'handicapped', the outcome decides which educational program the students are placed into (Mehan 1991); Unemployed people attending vocational guidance are dependent upon guidance officers' understanding and acceptance, and they may have to convey accounts which seek to categorize their identities in accordance with institutional specifics and societal standards (Mäkitalo 2003). In sum, categories can be said to be "activity bound and intrinsic to institutional practices" (Mäkitalo/Säljö 2002: 75).

The process of discharging elderly patients from geriatric wards is also, to a large extent, a matter of agreeing upon the relevant categories: how disabled are the patients and which solutions seem to fit them the best? An illustration may be seen in the following short excerpt. The excerpt is somewhat different from the main focus of this article. The account of why the patient is being referred to a residential home in this particular case is not directed to the patient herself, but rather to the system. Specifically, in this situation the representative is engaged in making notes in the patient's file. This file is sent to the municipality afterwards. In the excerpt, the representative asks the patient what she should note as the reason for why the patient wishes to move into a residential home.

(1): Security $(\mathrm{RE}=$ municipal representative, $\mathrm{PA}=$ patient $)$

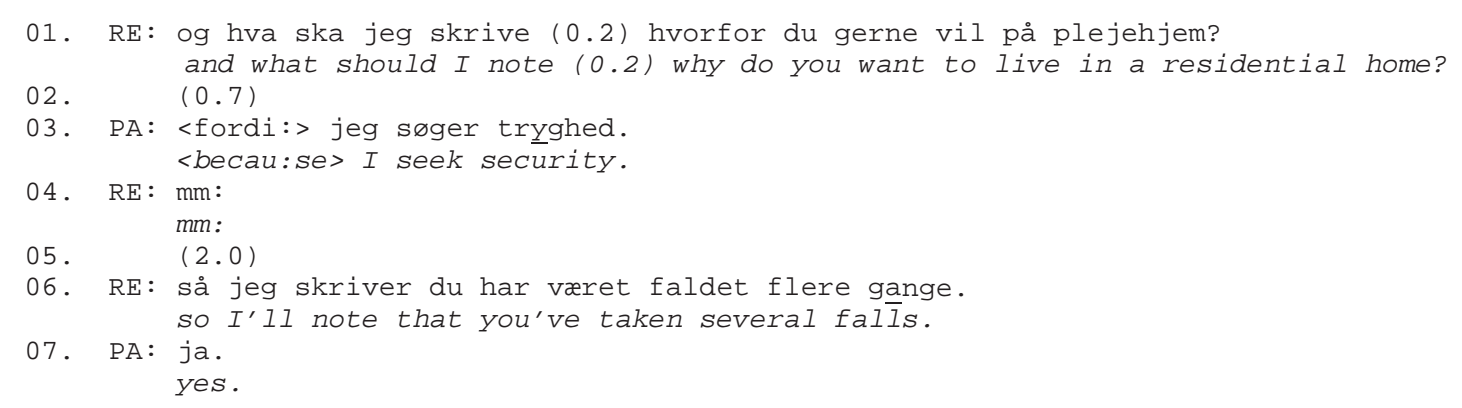

Probably the most noticeable thing about excerpt (1) is that the representative implicitly, via an embedded correction, treats the fact that the patient has taken several falls as a better reason to apply for a place in a residential home than the patient's search for security. Such a priority is hardly surprising since 'security' is a far more abstract term than the tangible 'taking falls'. But the interesting aspect is the representative's lack of explicitness; her contribution in line 06 corresponds to a phenomenon Gail Jefferson (1983) has described as an embedded correction. Unlike exposed corrections, embedded corrections do not convey an explicit correction of some element in the prior talk. The production of speech is not interrupted by attendant activities, or as Jefferson also calls them: accountings (Jefferson 1983: 90). By not explicitly orienting towards the patient's own reason for why she wants to live in a residential home, the representative, consciously or not, avoids clarifying what it takes for a senior citizen to be referred to a residential home, or what the proper social categories are.

In example (1) the representative alters the patient's explanation so that it is more suited for documentation. Texts, in various kinds, play an enormous role in institutional decision making. Official documents such as forms and leaflets to a large degree serve to maintain bureaucracy (see e.g. Sarangi/Slembrouck 1996: 127 ff.). We see just a small fraction of this in example (1). But 
characteristically the existence of a legal, textual practice where some disabilities fit certain residential solutions better than other is only hinted. The rest of the article will focus on situations where representatives present their accounts to the patients or to the patients' relatives. These situations illustrate that making an important professional decision, such as referring a senior citizen to a residential home, is not merely an accountable act in terms of the system, but also to the patient in the situation. The remaining examples share an important similarity with excerpt (1). These examples show that decisions are not justified with reference to rules and regulations. What it, in a legal sense, takes for a person to be referred to a residential home is not clarified. Policies vary from municipality to municipality, but commonly accepted attempts to standardize how to talk about and assess the needs for help have been made. The probably most used of them is the so-called 'common language catalogue' which was designed by the joint Local Government in 1998. The common language catalogue divides elderly citizens into four different levels according to their abilities; level 1 implies that the elderly is in no particular need of substantive help at the moment, level 4, on the other hand, implies that the person is not able to take care of him- or herself at all. Each level is defined according to concrete practical tasks. Say, for instance, if the elderly person is able to take care of personal hygiene or not. Coding schemes, such as the common language catalogue, are frequently invoked by professionals in order to reach mutual understanding with laypersons, see e.g. Goodwin (1994). But in no instances in the dataset do representatives or other health care professionals refer to standardized assessment criteria, let alone refer to legal documents. As we shall see in this paper, they evoke much more person-to-person specific assessment arguments. Perhaps the most salient way to evoke individual assessment in the data is for the representative to present considerations with regards to the elderly citizen's progression. This method is documented in this paper.

Representatives account for their decisions about whether or not patients are to be referred to residential homes in a series of turns in talk. That is, such accounts unfold over relatively long stretches of time. In order to provide an illustration of how such accounts unfold, the remainder of this paper shall limit its scope to two representative cases from the corpus of geriatric case conferences. In both instances a patient is discharged from the hospital, and in both instances the patient expresses a request for a place in a residential home. In the first case study, this request is accepted; in the second case study, the patient's request is denied. In both instances, representatives introduce an element of progression in their accounts. In the first case study, one of the explicit reasons why the patient is offered a place in a residential home is the claim that her condition has worsened considerably. In the second case study, an explicit reason for why the patient is denied a place in a residential home is the claim that her condition has improved considerably.

\section{Case study 1: accepting the patient's request}

The first case study concerns a female patient who suffers from loss of memory and loss of balance. She was hospitalized after taking falls in her own home. At the hospital, the staff found that she had had some blood clots. Those blood clots are presumed to be the reason for her loss of memory and balance.

Apart from the patient (PA) herself, Hannah, five other persons participate in the case conference: a doctor and head of this particular geriatric ward (DO); a representative from the municipality who is in charge of the distribution of home-help care and placement in residential homes (RE); the patient's daughter, Lisa; a nurse; and finally, the patient's grandson. Prior to the sample the doctor has told the patient how an occupational therapist has assessed her general condition. The doctor ends her report by noting that the occupational therapist is concerned that the patient lives in a house with several staircases:

(2): accepting the patient's request 
01. D0: men de:r nogen ting som som gør at hun er lidt bekymret=>oss 02. but there are some things which cause her to worry a little $=>$ for
02. det der at du bor $i$ det hus med tre:dje eta:ge og bad instance the fact that you live in a house with a third floor and bath

03. $\quad$ i kælderen og ø:h soveværelse på forste sal=og de:t 个ikk in the basement and e:rhm bedroom on the first floor=and Tthat's not

04. $\quad$ godt . $<$ very Tgood.<

๑5. PA: <de: [t jeg selv blevet klar over.> $<I^{\prime} v[$ e become aware of that myself. $>$

๑6. D0: [altså med de problemer du har er det ikk godt $(0.8)$

[I mean with the problems you have that's not very good.

๑8. D0: .h så det var sådn set=>det var jo formålet med vores snak

.h so that was sort of=>that was the purpose of our talk

๑9. $\quad$ i dag=det var at find: ud af (.) og hva så.< today=that was to find out (.) now what. $<$

10. $\quad(3.3)$

11. PA: jamen jeg ka jo 个ikk ba:re si:ge (.) j jeg vil gerne (๑.4) på en eller well but I Tcan't just say (.) I I would like (0.4) a or

12. $i$ en besky:tet bo:lig eller på et plejehjem (1.2)

to live $i \bar{n}$ a sheltered residence or $\bar{a}$ place in a residential home (1.2)

13. fordi de:t ka jo (1.3) it godt (1.3) der [ka] godt gå lang tid.

14. DO : cause certainly that can (1.3) might (1.3) [take] a long time. 15. RE: $<{ }^{\circ} \mathrm{n}\left[\mathrm{ee}: j\right.$ det $^{\circ}$ gør der faktisk ikk Hannah.>

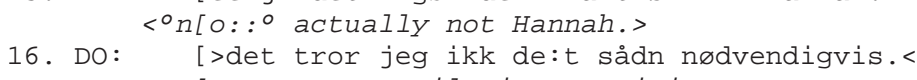

17. PA: gør der ikk? doesn't it?

18. RE: ${ }^{\circ}$ nee: $j^{\circ}(0.7)$ og nu har jeg jo snakket lidt med=ø:h Lisa=jeg har

${ }^{\circ}$ no:: ${ }^{\circ}(\odot .7)$ and $I^{\prime}$ ve been talking a little bit to=erhm $L i s a=I^{\prime} v e$

19. fået pa个pirer ude fra hospitalet. (0.4) som beskriver nogle af

been given Tpaperwork from the hospital. (0.4) which describes some of

20. her (.) ting. (๑.6) og Lisa har oss fortalt mig (.) vi har these (.) things. (๑.6) and Lisa has also told me (.) we have been

21. snākket sammen $i$ telefonen nogle gange (.)så jeg har oss sadn ligesom talking together on the phone a couple of times (.) so I've also sort

22. fåt at vide hvordan (0.6) og jeg ka jo oss (.) tydeligt se (.) at of been told how $(0.6)$ and I can certainly also (.) clearly see (.) that

23. din hukommelse den er blevet forværret fra da du ${ }^{\circ}$ var $\overline{d e r h j e m m:{ }^{\circ}}(0.8)$ your memory is worsened from when you were back home ${ }^{\circ}(0.8)$

24. og der har oss været flere fald, and there have also been some more falls,

25. PA: ०oja de:t rigtigt. $\circ$

oyes that's right. ${ }^{\circ}$

26. RE: så for den led (.) så syns jeg vi snakker noget (.) der hedder

27. on that account (.) I think we're
plejehjem=og de: $r$ ikk lang ventetid. residential home=añ d there is not a long waiting time.

The main focus of interest in excerpt (2) will be the representative's explanation of why the patient is entitled to be referred to a residential home, in lines 18-24 and 26-27. But in order to fully grasp this explanation, a brief investigation of its responsiveness towards the preceding turns of talk is required. The doctor's summary of the case conference's purpose (lines 8-9) makes it relevant for the patient to express where and how she would like to live after she is discharged from the hospital. But does this imply that she can request whatever kind of solution she might like? In lines 01-04 and 06 the doctor voices the occupational therapist's concerns regarding the staircases in her own home. This explanation would make it more difficult for the patient to say that she wanted to move back into her own home. But apart from this precaution, the patient appears to be able to make whatever kind of request she would like, judging by the doctor's invitation in lines 08-09. The patient's reply (lines 11-13) conveys surprise that this may be the case, and furthermore, it conveys what is understood by the doctor and the representative as a request to live 
in a residential home. This seemingly cautious request is accepted by the representative and the doctor, almost in unison, through a dismissal of the proposal that the patient is not entitled to suggest this solution (lines 15-16). The patient then produces a repeat question (line 17) which, once more, is disconfirmed (line 18). There is a notable similarity in the design of these dismissals doing the job of acceptances. Both are designed with a prolonged 'no'. In line 15 the prolonged 'no' is placed turn-initial followed by an elaboration which with the adverb 'actually' (Danish: faktisk) orients towards the patient's assumption being relevant and likely, but not an issue in this particular case. In line 18 the prolonged 'no' is followed by a pause and then the series of accounts in mention. Neither of the tokens are, then, followed by signs of indecisiveness (as prolonged no in response to yes/no questions has also been documented to signal, see Lind 2007). Prolongation of words and sounds may construe a response as dispreferred, that is, socially problematic (Schegloff 1988). This regularly occurs in cases of dismissals (Davidson 1984). But, in this particular case, the dismissals actually anticipate acceptance of the patient's cautious request. The prolongation here seems to be attentive to dismissing the patient's assumption and, at the same time, paving the way for more elaborative explanation of reasoning. In line 18 the subsequent series of account is tied to the prolonged 'no' with an 'and' (Danish: 'og'). Hereby, the representative makes it clear that she is about to present something more additional than merely the dismissal/confirmation she produced in line 15 .

In lines 11-13 the patient has herself introduced two seemingly desirable options for future residency: a sheltered residence or a place in a residential home. The representative ends up advocating the latter solution (line 27). A noticeable thing about the representative's explanation in lines 18-24 and 26-27 leading up to the advocacy of a residential home placement is the fact that she invokes different perspectives to illuminate the patient's condition and to account for why the patient is entitled to be referred to a residential home, and why she considers this to be the best solution. Three are invoked: the daughter Lisa's views, insights from the hospital paperwork, and finally, the representative's own observations. The representative appears to initiate a total of five different arguments in support of her overall acceptance of the patient's request. However, another noticeable thing about the explanation is that it contains several restarts, three to be exact (lines 18, 20 and 22). These restarts interrupt the flow of speech, and consequently, leaves the first three of these five arguments somewhat under-informative: the representative mentions having talked to Lisa, but she does not elaborate upon what they talked about. She mentions having received paperwork from the hospital describing some of 'these things', but she does not clarify what 'these things' refer to. They may refer to what is elaborated later in the same turn, that is, that the patient has taken some more falls and/or that her memory has worsened lately. But if that is the case, it is not made explicit. Finally, she once again mentions having talked to Lisa, this time on the phone. The representative informs the patient that she has been told 'how' by Lisa, but she does not explain what this 'how' refers to. Of the five arguments, only the last two are completed. Using the argument of aggravation, the representative explains that she has observed how the patient's memory has worsened, and she explains that the patient has taken more falls.

Excerpt (2) illustrates the power of development claims. In this particular case, a claim of aggravation is introduced as the final punctuation before the representative (in line 26) makes it clear that she considers the patient to be entitled to live in a residential home, and (in line 27), in the words of Bakhtin (1986: 76), produces a "concluding dixi" making it clear that she has nothing more to add. The assurance that not only is the patient entitled to a place in a residential home, but she will not have to wait a long time to get such a place (line 27) ties the representative's response to the wordings of the patient's request (line 13). In the context of question-answer adjacency pairs in news interviews, this is a technique which is often used to signal that "the spate of talk which had been unfolding now constitutes a possibly complete answer" (Clayman/Heritage 2002: 248). However, excerpt (2) also illustrates that claims of development do not necessarily explicate the legal grounds on which patients are referred to residential homes. The representative presents the patient's loss of memory as an observable fact, but she does not specify precisely how good it 
used to be or how bad it has become. Furthermore, the representative does not specify how infrequently the patient used to fall and how frequently she falls now. The representative's explanation may be compared to a mosaic ${ }^{2}$. It is difficult to apprehend a mosaic when viewed very close up, but upon stepping back, its structure and motive emerges. It may be argued that each element in the representative's explanation is somewhat under-informative, but combined they form a concise and pessimistic image of the patient's present condition, and thus, an adequate explanation of why she is entitled to live in a residential home. And, as we see in line 25 , the patient agrees and accepts the explanation as adequate. This is another characteristic which excerpt (2) illustrates: patients' uptakes to the accounts are generally positive (or neutral). The next case study shows that this is also the case even when their requests are denied.

\section{Case study 2: denying the patient's request}

The next sample to be considered concerns a patient who was also hospitalized after she had taken a fall in her own home. At the hospital, she was diagnosed as having chronic bronchitis. She has trouble walking (at this case conference she sits in a wheelchair, but she is being trained to walk with a rollator) and breathing (at this case conference she wears an oxygen mask which is attached to her nose, but she is being trained to breathe without it).

When the patient is to be discharged from the hospital, five persons participate in the case conference: the patient herself (PA); her two daughters (D1 and D2); a municipal representative (RE); and a nurse. At the very beginning of this case conference, the patient has stated that she wishes to move into a certain residential home situated next to where one of her daughters lives. Fifteen minutes later, and immediately prior to the sample below, the representative has dismissed that option. Instead, the representative has suggested that the patient moves temporarily into a retraining facility for elderly citizens. This solution leaves open that the patient might move back into her own home after the retraining program is over, and it prompts the patient to assert that she will never again move back into her own home. Upon this assertion, the representative poses the following question:

2 This metaphor was suggested to me by John Heritage (personal communication). 
(3): denying the patient's request

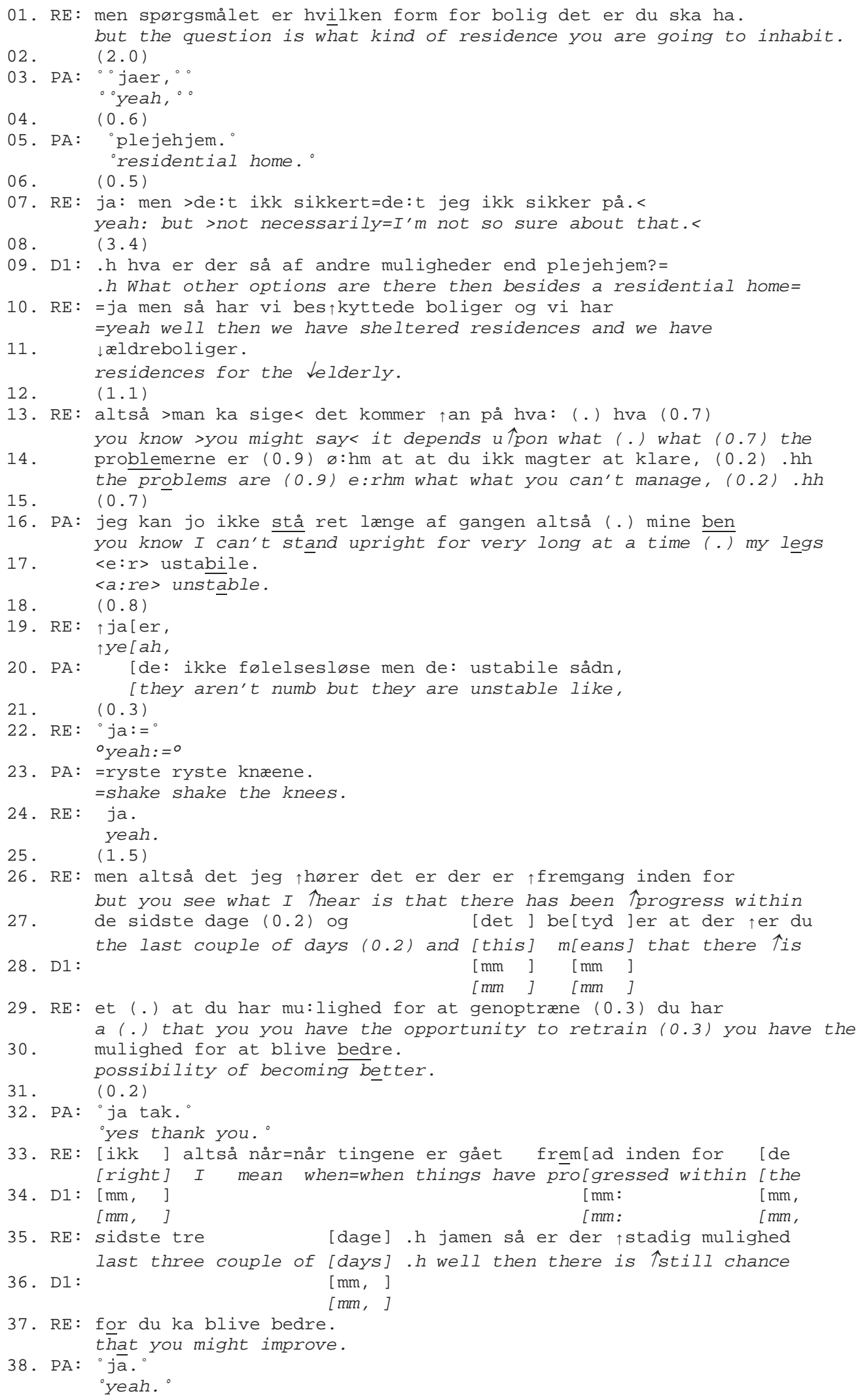

Clearly, the representative and the patient differ in their opinions about where the patient should live when she is discharged from the hospital. In a cautious way (i.e., delayed and soft spoken), 
the patient once more proposes that she moves into a residential home (line 05), and, once again, the representative dismisses this solution (line 07). Flat out refusals to offers, requests and invitations make it relevant for actors to explain the refusal (Antaki 1994: 80-81). And in this case, this is also what the representative does. It is well worth noting that in spite of the open question format which prompts the patient's request (line 01), the representative in line 07 treats the residential home proposal (line 05 ) as a dispreferred answer which fails to take several other perspectives into account, notably options such as a sheltered residence or a residence for the elderly ${ }^{3}$ (lines 10-11). Thus, having corrected the patient, the scene is set for a thorough explanation of why something is the right answer. Indeed, in the first part of the representative's account (lines 13-14), she explains the basic municipal principles of distribution of residencies among the elderly. This explanation directs the patient's attention to the fact that there are standards, or a set of criteria, which needs to be taken into account. From this account there appears to be a standard solution to a given set of problems ("you might say it depends upon what the problems are"). This prompts the patient to argue that her bad legs might qualify her for a place in a residential home. In lines 16-17 (and subsequently 20 and 23) the patient seeks to convince the representative that her condition is so weakened that she qualifies for the criteria laid out by RE. But not very successfully. A prolonged, rising 'yeah' (line 19) marks the representative's scepticism, makes the patient elaborate (line 20) and illustrate (line 23) the claim of weakening. Retrospectively, it also anticipates the final dismissal (line 24 and onwards). This final dismissal is initiated with separated 'yes' 'but'. Such a turn design has been documented to orient strongly towards social problematicity (Steensig/Asmuß 2005). The representative does not directly contradict the patient's claim of impaired walking, but from line 26 onward she explains why the patient still cannot be referred to a residential home. Twice she accentuates the patient's progress within the last couple of days (lines 26-30 and 33-37). Though it is never said aloud, the logic seems to be that further improvements may lead to independence, which would enable the patient to do without a place in a residential home.

Other studies have shown that health care professionals tend to produce reinterpretations of geriatric patients' often pessimistic, bordering on self-deprecative, assertions about their situation and abilities, these reinterpretations move in more optimistic directions (Beck Nielsen 2009; Coupland/Coupland 1998). Here, the representative's accounts seek to make the patient accept a different solution than the one she had imagined. In one of his early writings, Erving Goffman (1952) suggests that people who suffer an involuntary loss may have to be cooled down by the operators who have brought the loss upon them (e.g., the conman who has tricked a mark or the boss who has fired a worker). An involuntary loss involves some sort of new unfavourable identity. For the person who has experienced the loss, cooling down represents a process of adjustment to a seemingly impossible situation. This means that operators must present this person with "a new framework in which to see himself and judge himself" (Goffman 1952: 456). One of the strategies Goffman proposes as a way of cooling a person down is to convince that person that his or her loss is actually a gain. This seems to be what the representative is doing. She designs her refusal of the patient's request as a great opportunity for the patient to improve. It is difficult to tell to which extent this strategy is felicitous at this particular moment. The patient aligns with the representative's positive prognoses (lines 32 and 38), but the responses do not appear very enthusiastic. For instance, in line 32 the patient responds with a 'yes' followed by a 'thank you'; at least in English, such display of acknowledgement is a very common way to respond to a compliment (Pomerantz 1978). It would, thus, appear that the patient is more occupied with responding in an expected way than expressing her enthusiastic agreement. Nevertheless, she does formally align, in compliance with the tendency for patients to respond positively or neutrally to representatives' accounts.

3 These two types of residences are typically small, ground-floor flats where citizens live on their own (unlike in residential homes). They have facilities which make them particularly suited for disabled persons; for the municipality, they are a less costly solution than residential homes. 
Overall, the representative's series of accounts convey the reasons why the patient is denied a place in a residential home. But, as in the previous case study, we see that little information regarding rules and regulations is conveyed. Some is hinted, but very little made explicit, let alone elaborated. When the representative explains the basic municipal principles of residency distribution (lines 13-14), she does not illuminate the precise number or severity of the problems citizens must have in order to be referred to a residential home. And when the representative addresses the more concrete issue of this patient's particular problems, she does not elucidate what the so called chance of improvement covers. Instead a developmental discourse is used as a cooling strategy to reach a common agreement.

\section{Discussion}

These two case studies have illustrated how municipal representatives account for their decisions about whether or not an elderly person is to be referred to a residential home during geriatric case conferences in Denmark. The representatives in this study put a substantial effort into producing such accounts; they treat their decisions as social accountable actions in situ. But at the same time they tend to avoid explicitness about their criteria. In this sense, the accounts might be viewed as somewhat under-informative. But they are not from the participants' perpectives. They are produced as adequate explanations of the representative's decisions, and they are accepted as adequate contributions by the patients, their relatives and the other parties of geriatric case conferences. According to Harold Garfinkel, this apparent discrepancy is anything but uncommon. Garfinkel has argued that members' accounts of everyday activities are loose (2003: 2-4). Both the notion of accounts and of everyday activities is to be understood in the broadest sense. The issue of 'looseness' refers to Garfinkel's finding that accounts of everyday activities are always adapted to the circumstances in which they are used, and crucially, are thought to be motivated, meaningful and adequate contributions by fellow social actors, however underspecified or sparse they may be (Garfinkel 2003: 4; see also Garfinkel 1963; Heritage 1984). Accounts of everyday activities, therefore, rely heavily upon the mutual assumption of common understanding. In fact, one of Garfinkel's so-called breaching experiments illustrated that if a person repeatedly insists that fellow interlocutors explain their accounts of everyday activities in further detail, the process results in a (momentary) breakdown of the interaction (Garfinkel 2003: 38 ff.).

The fact that representatives' accounts of their decision-making practices are accepted as adequate explanations during geriatric case conferences, in spite of the sparse amount of concrete information about municipal principles they convey supports Garfinkel's claim. Furthermore, this fact elaborates the claim. The representatives' accounts are indeed made relevant in the local context. In the first case study, the representative's account is prompted by the patient's assertion that it is not possible for her to move into a residential home immediately. This assertion is responded to as an implicit, cautious request for a place in a residential home, and this makes it relevant for the representative to explain why this actually is possible. In the second case study, the representative's account is made relevant by the patient's argument that she is entitled to live in a residential home. Thus, there are important differences in the way the two patients make requests to live in residential homes: the patient in the second case study demonstrates a much higher degree of entitlement than the patient in the first case study, see Heinemann (2006). One might also argue that the very nature of the representatives' decisions makes these accountable actions. Such decisions are of extreme importance to the patients. Residential homes are institutions which residents most commonly inhabit until they pass away. Accommodations or rejections of requests for places in residential homes are, thus, decisions which determine where the patients are to live for the rest of their lives.

One might wonder if detailed, in depth and technical accounts of the decision-making process for accommodating or rejecting requests for residential home placement are indeed in the patients' own interests. Geriatric patients are very often to some degree mentally disabled; loss of memory, aphasia or dementia is frequently found among the patients' mental disabilities. Further- 
more, many patients are hard of hearing. Such impairments and disabilities may make it difficult, if not impossible, for some patients to grasp detailed accounts, and the general sparseness of the accounts may very well be the result of the representatives' consideration of such matters. One of the most important consequences of the accounts' sparseness may then be maintenance of symmetry among the participants, in particular with respect to the patients' possibilities for active participation. However, another important consequence may be the exact opposite: that is, establishment of asymmetry among the participants. If municipal representatives refuse to accommodate residential homes requests without explaining the criteria for which citizens are referred or not referred to residential homes, it may prove very hard for the patients and their relatives to argue against the decision.

\section{Conclusion}

This paper has illustrated how municipal representatives account for their decisions about whether to accommodate or refuse requests for residential home placement during Danish geriatric case conferences. Representatives do explain their reasons for accommodating or refusing such requests in situ, and thus transcend the talk-in-interaction from a taken-for-granted level of reasoning to a level of overt explanation. However, detailed analyses reveal that representatives' accounts do not give much information about the criteria under which citizens are referred or not referred to residential homes. Such criteria are not given. Yet, these accounts are accepted as adequate contributions by the patients and their relatives in situ. The accounts' uptakes are neutral or positive and there are no requests for elaboration. The sparseness of the accounts and the acceptance they nonetheless receive supports Harold Garfinkel's claim that actors assume each other's conversational contributions to be motivated, relevant and adequate, and that common understanding is achieved through this mutual assumption.

\section{References}

Antaki, Charles 1994: Explaining and Arguing. The Social Organization of Accounts. London: Sage Publications.

Austin, John L. 1961: A Plea for Excuses. In Austin, J. L., Philosophical Papers. Oxford: Oxford University Press, 175-204.

Bakhtin, Mikhail 1986: Speech Genres and Other Late Essays. USA: University of Texas Press.

Beck Nielsen, Søren 2009: Accounts on the Behalf of Patients During Geriatric Case Conferences. In Research on Language and Social Interaction 42(3), 231-248.

Buttny, Richard 1993: Social Accountability in Communication. London: Sage Publications.

Christiansen, Niels Finn/Petersen, Klaus 2001: The Dynamics of Social Solidarity: The Danish Welfare State, 19002000. Scan. J. History 26, No. 3, 177-196.

Clayman, Steven/Heritage, John 2002: The News Interview. Journalists and Public Figures on the Air. Cambridge: Cambridge University Press.

Coupland, Nicolas/Coupland, Justine 1998: Reshaping lives: Constitutive identity work in geriatric medical consultations. In TEXT 18(2), 159-189.

Davidson, Judy 1984: Subsequent versions of invitations, offers, requests, and proposals dealing with potential or actual rejection. In Atkinson, Maxwell J./Heritage, John (eds.), Structures of Social Action. Studies in Conversation Analysis. Cambridge: Cambridge University Press, 102-128.

Drew, Paul 1984: Speaker's reportings in invitation sequences. In Atkinson, Maxwell J./Heritage, John (eds.), Structures of Social Action. Studies in Conversation Analysis. Cambridge: Cambridge University Press, 129-151.

Drew, P. 1992: Contested evidence in courtroom cross-examination: the case of a trial for rape. In Drew, Paul/Heritage, John (eds.), Talk at work. Interaction in institutional settings. Cambridge: Cambridge University Press, 470-520.

Garfinkel, Harold 1963: A Conception of, and Experiments with, "Trust" as a Condition Stable Concerted Actions. In Harvey, O. J. (ed.), Motivation and Social Interaction. New York: The Ronald Press Company, 187-238.

Garfinkel, Harold 2003 [1967]: Studies in Ethnomethodology. Cambridge: Polity Press.

Goffman, Erving 1952: On Cooling the Mark Out. In Psychiatry: Journal of Interpersonal Relations 15:4, 451-463.

Goodwin, Charles 1994: Professional Vision. In American Anthropologist 96(3), 606-33. 
Goodwin, Marjorie Harness 1998: Games of Stance: Conflict and Footing in Hopscotch. In Hoyle, S./Temple Adger, C. (eds.), Kids’ Talk: Strategic Language Use in Later Childhood. New York: Oxford University Press, 23-46.

Goodwin, Charles/Goodwin, Marjorie Harness 1990: Interstitial Argument. In Grimshaw, A. (ed.), Conflict Talk. Cambridge: Cambridge University Press, 85-117.

Heinemann, Trine 2006: Will you or can’t you? Displaying entitlement in interrogative requests. In Journal of Pragmatics 38, 1081-1104.

Heinemann, Trine 2008: Questions of accountability: yes no interrogatives that are unanswerable. In Discourse Studies 10(1), 55-71.

Heritage, John 1983: Accounts in Action. In Gilbert, N./Abell, P. (eds.), Accounts and Action. Farnborough: Gower House, 117-131.

Heritage, John 1984: Garfinkel and Ethnomethodology. Cambridge and New York: Polity Press.

Heritage, John 1988: Explanations as Accounts: A Conversation Analytic Perspective. In Antaki, C. (ed.), Analyzing Lay Explanation: A Case Book of Methods. London: Sage, 127-144.

Heritage, John/Atkinson, Maxwell J. 1984: Introduction. In Atkinson, Maxwell J./Heritage, John (eds.), Structures of Social Action. Studies in Conversation Analysis. Cambridge: Cambridge University Press, 1-15.

Jefferson, Gail 1983: On exposed and embedded correction in conversation. In Studium Linquistik 14, 58-68. [Reprinted in Button, G./Lee, J.R.E. (eds.) 1987, Talk and social organization. Clevedon, UK: Multilingual Matters, 86-100.]

Levinson, Stephen C. 1983: Pragmatics. Cambridge: Cambridge University Press.

Linell, Per/Fredin, Erik 1995: Negotiating terms in social welfare office talk. In Firth, A. (ed.), Negotiation in Workplaces: Discourse and Interactional Perspectives. New York: Pergamon, 299-318.

Lind, Marianne 2007: Prosodic contextualization of minimal responses to yes/no-questions in aphasic talk-in-interaction: A descriptive single-case study of a Norwegian aphasic speaker. In Logopedics Phoniatrics Vocology 32, 9-16.

Mäkitalo, Åsa 2003: Accounting practices as situated knowing: dilemmas and dynamics in institutional categorization. In Discourse Studies, Vol 5(4), 495-516.

Mäkitalo, Åsa/Säljö, Roger 2002: Talk in context institutional and institutional context in talk: Categories as situated practices. In Text 22(1), 57-82.

Maynard, Douglas W./Manzo, John 1993: On the Sociology of Justice: Theoretical Notes from an Actual Jury Deliberation. In Sociological Theory 11, 171-193.

Maynard, Douglas W./Schaeffer, Nora Cate 1997: Keeping the Gate: Declinations to Participate in the Survey Interview. In Sociological Methods and Research 26, 34-79.

Mehan, Hugh 1991: The School's Work of Sorting Students. In Boden, Deidre/Zimmerman, Don H. (eds), Talk \& Social Structure. Studies in Ethnomethodology and Conversation Analysis. Cambridge, UK: Polity Press, 70-71.

Mills, Charles Wright 1940: Situated Actions and Vocabularies of Motive. In American Sociological Review, Vol. 5 (6), 904-913.

Pomerantz, Anita 1978: Compliment responses: notes on the co-operation of multiple constraints. In Schenkein, Jim (ed.), Studies in the Organization of Conversational Interaction. New York: Academic press, 79-112.

Prottas, Jeffrey Manditch 1979: People-processing. The street-level bureaucrat in public service bureaucracies. Lexington, MA: Lexington Books.

Sacks, Harvey 1992: Lectures on Conversation. Vol. 1. Oxford UK/Cambridge USA: Blackwell.

Sarangi, Srikant/Slembrouck, Stefaan 1996: Language, Bureaucracy and Social Control. London: Longman.

Schegloff, Emmanuel. A. 1988: On an Actual Virtual Servo-Mechanism for Guessing Bad News: A Single Case Conjecture. In Social Problems 35, 442-457.

Schegloff, Emmanuel A. 2005: On Complainability. In Social Problems 52(4), 449-476.

Scott, Marvin B./Lyman, S. M. 1968: Accounts. In American Sociological Review 33, 46-62.

Shotter, John 1984: Social Accountability \& Selfhood. Oxford: Blackwell.

Steensig, Jakob/Asmuß, Birte 2005: Notes on disaligning 'yes but' initiated utterances in German and Danish conversations. In Hakulinen, Auli/Selting, Margeret (eds.), Syntax and Lexis in Interaction. Amsterdam/Philadelphia: John Benjamins Publishing Company, 349-373. 
